\title{
Değișen Tüketim Pratikleri Bağlamında Hızlı Moda
}

\author{
Hilal ÖZTAY*
}

Öz

Örtünmenin, yerini giyinmeye bıraktı̆̆ı dönemlerden yalnızca yüz yıl gibi yakın bir zamana kadar seçkinlerin tekelinde olan moda ve moda tüketimi, alt sınıflar ya da sıradan vatandaşlar için ulaşılması zor olan hatta çeşitli şekillerdeki yaptırımlarla kısıtlanan bir davranış kalıbı olmuştur. Ancak, üretim yapısındaki değişim ve bunun sonucunda tüketim pratiklerin de değişmeye başlamasıyla, moda ürünler de diğer tüketim nesneleri gibi nispeten ulaşllabilir bir hale gelmiş ve toplumdaki tüm kesimler tarafından kullanılmaya başlanmıştır. Süreç içerisinde modaya dair metalar, kavrama yüklenen anlamın da değișmesiyle birlikte en çok kullanılan ve en sık değiștirilen ürünler olarak karşımıza çıkmaktadır. Bu dramatik değişim, tüketimin genel yapısındaki farklılaşmadan ve içerisinde bulunduğu toplumsal değişim dinamiklerinden soyutlanarak anlașılamaz. Bu çalıșmanın amacı, tüketimi eleștirel bir bakış açısıyla ele almaktan öte, tarihsel perspektifte tüketim pratiklerinin değișimine ortam sağlayan gelişme ve olguların neden sonuç ilişkileri ile değerlendirilmesidir. Böylelikle günümüzdeki moda tüketiminin dinamikleri hakkında bakış açısı sunulmuş olacaktır.

Anahtar Kelimeler: Hızlı moda, Moda tüketimi, Tüketim pratikleri, Türkiye'de tüketim, Türkiye'de hızlı moda

\section{Fast Fashion, in the Context of Changing Consumption Practices}

\section{Abstract}

Fashion has been under the monopoly of the elite from the time when veiling left its place to dress, to only a hundred years ago. Fashion consumption has been a behavior that is difficult to reach for lower classes or ordinary citizens and fashion actions have been restricted by sanctions. But, with the change in the production structure and consequently consumption practices began to change, fashion products became relatively accessible like other consumption objects and started to be used by all segments in the society. In the process, with the change of the meaning of the concept, fashion products have become the most used and most frequently changed products. This dramatic change can't be understood with isolate from the differentiation in the general structure of consumption and the social change dynamics in which it is located. The purpose of this study is not to consider consumption from a critical perspective. It is the review of the developments and facts that cause the change of consumption practices with the cause and effect relationships from a historical perspective and to provide a perspective on the dynamics of today's fashion consumption.

\section{Derleme Makale (Review Article)}

Geliş/Received: 10.02 .2020

Kabul/Accepted: 24.05 .2020

DOI: https://dx.doi.org/10.17336/igusbd.695624

* Öğr. Gör. Dr., Kastamonu Üniversitesi, Araç Rafet Vergili Meslek Yüksekokulu, Kastamonu, Türkiye, E-posta: hoztay@kastamonu.edu.tr ORCID https://orcid.org/0000-0002-1904-7963 
Keywords: Fast fashion, Fashion consumption, Consumption practices, Consumption in Turkey, Fast fashion in Turkey

\section{Giriş}

Moda, insanın ruhuyla șekillenen bir davranıștır. Aynı șeylere maruz kalan insanın duyduğu bıkkınlık ve bu bıkkınlığa karşı yenilik arayışı, duyuların yenilenmesi alanında karşımıza moda olarak çıkmaktadır (Pektaş, 2006: 198). Moda ürünlerin temel karakteristiği yaşam eğrilerinin kısa olması ve estetik özelliklerinin işlevsellikten çok daha fazla ön planda bulunmasıdır (Tüfekçi, 2014: 50). Moda kavramı pek çok sektördekine benzer șekilde hazır giyim sektöründe de, sürekli değişimi ifade eden bir kavramdır (Çalışkan, Karacasulu ve Öztürkoğlu, 2016: 57).

Moda giyim endüstrisi özellikle son yıllar içerisinde oldukça önemli değişiklikler göstermiştir (Bhardwaj ve Fairhurst, 2010: 165). 21. yüzyll ile birlikte birçok endüstri dalında olduğu gibi hazır giyim sektöründe de tüketici istekleri değişmiș, çeșitlenmiş ve hızlanmıştır (Dal ve Gürpınar, 2010: 21). Günümüzde teknolojinin de hızla ilerlemesi sonucu hazır giyim sektöründe modaya sadece tüketici tercihleri değil teknoloji de yön vermektedir. Teknolojinin hızla ilerlemesi modanın değișim sürecini de hızlandırmıș, bu da giderek rekabeti arttırmıștır (Çalıșkan vd., 2016: 57).

Hızla değişen dünyada müşteri beklentilerini ve ihtiyaçlarını doğru ve verimli bir şekilde karşılamak çağdaş pazarlamanın ana felsefesidir (Aksu, Pektaş ve Karaboğa, 2011: 3). Tüketiciler, sezon başlarında trend olan ürünleri takip etmekte ve bu ürünleri en kısa sürede elde etme güdüsüyle davranmaktadır. Ürünün renk, kalite, desen gibi özelliklerine ilaveten o sezon moda olması bile tüketiciler tarafından tercih edilmesine neden olur. $\mathrm{Bu}$ durum, modanın tüketicilere hızlıca ulaştırılmasını sağlayan hızlı moda kavramını karşımıza çıkarmaktadır (Tüfekçi, 2014: 50).

Hızlı moda pazar tezgâhlarında satılan basit ve ucuz kıyafetlerden, özel markalara, Zara ve Mango gibi kısmen Çin'de üretilen markalardan, hepsinden daha hızlı olan İskandinav markası H\&M'e kadar pek çok çeșitli markayı kapsayan genel bir terimdir (Segre, 2005: 47).

Hızlı moda kavramının temeli, merkezde müşteri olmak koşuluyla isteklere en kısa zamanda cevap vermektir. Değișen ve çeşitlenen müşteri isteklerine olabildiğince kısa sürede cevap verebilmek bugün birçok hazır giyim firmasının sahip olmak istediği ayrıcalıklardan birisidir (Dal ve Gürpınar, 2010: 21).

Byun ve Sternquist’a göre modayla ilgili değerleri etkileyen iki kritik nokta vardır. Bunlar fiyat ve yapay kıtlıktır (2008: 137). Bu kriterler hızlı moda kavramının doğasında mevcut haldedir. Yapay kıtlık moda perakendecilerinin kullandığı bir stratejidir. Ürünler belirli sayılarda sunularak, ürün çeşitliliği için kısa bir yenileme döngüsü sağlanır böylelikle yeni ürünler için boşluk yaratılmış olur. Böylelikle ürünlere ulaşım sınırlıdır ve bu ürünlere gelecekte bir zamanda da ulaşılmasının mümkün olmayacağı hissettirilir (Byun ve Sternquist, 2008: 138).

1950 sonrası Türkiye'de tüketim içsel ve dışsal faktörlere bağlı olarak artmış ve gelişmiştir. Dışsal faktörlere bakıldığında, dışsal politik nedenlere bağlı olarak refah uygulamaları yaygınlaşmıştır. İçsel faktörler ise tüketim kültürünün yaygınlaşması, tarım politikalarındaki değişim sonucunda yeni sınıfların yükselmesi ve ulaşım araçlarındaki gelişme neticesinde kentleşmenin ve toplumsal değişmenin hızlanmasıdır. Bu süreçte nüfus, tarımdan koparak kente yerleşmiştir. Dönemin en belirgin özelliklerinden biri tüketimin hız kazanması ve toplumun alt katmanlarına doğru yaygınlaşmaya başlamasıdır (Üstün ve Tutal, 2008: 263). 
20. yüzyılın sanayileșmiș toplumlarında iki taraflı bir ilişki karşımıza çıkmaktadır. Metalarla geniş ölçüde kurulmaya çalışılan sembolik ve anlamsal ilişki bir yanda, teknik ve tasarımsal yeniliklerle bu eşyaların yerini başkalarının alabileceği gerçeği bir yandadır. Günümüzde metaları miras bırakmak yerine, demode etmek, eskitmek ve elden çıkarmaya dayalı bir tüketim anlayışını söz konusudur. Bu değişim, insanların nesne dünyasıyla olan ilişkilerini, sanayi öncesi toplumlardaki gündelik eşyalara yönelik geleneksel iliş̧kilerle kıyaslandığında köklü biçimde değiștirmiştir (Dal ve Gürpınar, 2010: 39).

Eleştirel bir sorgulama konusu olarak modern toplumlardaki tüketim kavramına yoğun bir ilgi gösterilmesine rağmen, tüketim toplumuna ilişkin tarihsel çözümlemeler oldukça nadirdir (Yanıklar, 2006: 29). Tüketim kalıplarındaki radikal değişimlerin nedenlerini ve moda sektöründeki yansımalarını kavrayabilmek, hem dünya genelinde hem Türkiye özelinde tüketim pratiklerini değiștiren unsurların anlaşılması ile mümkündür. Bu da tarihsel ve sosyal açıdan bir kavrayış sağlarken, moda tüketicilerinin gelişmelere ve değişimlere tepkilerinin nasıl olduğunu ortaya koymak açısından da oldukça önemlidir.

\section{Tüketim Pratiklerinin Süreçteki Değişimi}

Post-fordist döneme geçişle birlikte, değişen kapitalist sistem, toplum yapısında belirleyici bir role sahip olan üretimin yanı sıra tüketimi de kendi sürekliliği ve başarısı için kullanmaya başlamış, böylelikle tüketim günümüzde kapitalist toplumlardaki vazgeçilmez ögelerden biri olmuştur. Kapitalizm, küreselleşmeyle birlikte sınırları aşan üretim çerçevesinde, aşırı üretim sorununu çözmek için bireyleri tüketime yöneltme yolunu benimsemiştir. Kapitalist sistemin varlığını devam ettirebilmesi için tüketime yönelik yeni gereksinimler yaratılmakta, böylelikle malların satışında artış hedeflenmektedir (Özdemir, 2009: 364).

Tüketim toplumunun şekillenmeye başladığı zamana dair bir dönem belirlemek zor olsa da, birtakım yazarlar bu tarz bir toplumun köklerinin 18. yüzyılda aranması gerektiğine inanırlar. Bu yazarların dayanakları, geçimlik üretiminden tüketim odaklı üretime geçilmesiyle, insanların kaçınılmaz bir şekilde tüketici olmaya başladıkları düşüncesidir (Yanıklar, 2006: 29).

Bir tüketim toplumunun varlığından bahsedebilmek için, öncelikle kitlesel üretimin yoğun olarak yaşandığı 20. yüzyılın başlarındaki Amerika'yı ele almak gerekir. Bu süreçte yaşanan üretim artışı tüketim artışını beraberinde getirmiştir. Mali sistemin ürettiği yeni ekonomik yatırım araçlarıyla kredi kaynakları buluşmuş, bu durum hızla kentlileşen göçmenlerin ve küçük kasaba topluluklarının çıkarına olacak şekilde işlemiştir (Tellan, 2009: 92). 19. yüzyıldan itibaren kitle tüketimi türleri, ödeme gücü olan elit sınıfın hâkimiyetindeydi, ancak 1920'lerden sonra daha alt tabakalar için de söz konusu olmaya bașlamıștır. Sanayideki gelișmenin artmasıyla seri üretim yöntemleri paralelinde kitlesel çapta üretim söz konusu olabilmiştir, standart tüketim kalıpları belirmeye başlamış, üretici tercihlerinin hâkimiyetindeki pazarların var olduğu Fordist dönem 1930'lardan 1970'lere kadar etkisini göstermiştir. Bu yaklaşım 1970'lerden sonra kaliteli ve sürekli değişim halinde olan modellere dayalı çeşitlilik ve değişiklik gösteren tüketici tercihlerinin ortaya çıkmasına sebep olmuş, ürünlerin ömürleri kısalmaya, model çeșitliliği artmaya bașlamıștır (Dal ve Gürpınar, 2010: 39).

Fordist seri üretimle birlikte, kitlesel tüketimin yanı sıra yeni tüketici grupları da belirmeye başlamıştır. Post-fordist üretim ise istek ve gereksinimleri çeşitlendirerek tüketimi arttırıp, çoğulcu bir hal almasını sağlamıştır. Bu gelişmelerle, tüketici grupları parçalanmış, yeni olan her şeyi tüketen bir mantığa dayalı olan tüketim ideolojisinin, ortaya çıkmasına ortam hazırlanmıştır (Karakaş, 2006: 4). Tüketim kültürüyle kitle 
kültürü arasındaki fark, post-fordist üretim uygulamalarıyla daha esnek, bireysel farklılıklar ve istekler göz önünde bulundurularak üretim yapılmasıdır (Kula, 2012: 510).

Teknolojideki gelişmeler sonucunda artan verimlilik, daha kısa zaman diliminde daha az harcayarak daha fazla ürün elde edilmesini sağlamıştır. Böylece bireyler kendilerine daha çok zaman ayırma imkânı bulmuştur. Artan boş vakit bireyleri diğer bireylerle daha fazla birlikte olmaya ve tüketim yapmaya yönlendirmiştir. Çağdaş toplumlarda statü belirleyicisi olarak, kişinin üretim miktarına göre değil, nerede ve nasıl tükettiğine bakılmaktadır (Aktaran Tüfekçi, 2014). Bireyin toplumdaki konumu, tükettikleriyle ölçülmektedir ve toplumda ancak tüketim yaparak bir konuma erişebileceği düşüncesi benimsetilmektedir. Bu durumu sağlamak için de reklamlar kullanılmaktadır (Çetinkaya, 1992).

Süreçteki değişime göre reklam metinleri bilgi verici ve dönüştürücü olmak üzere iki çeşittir. Bilgi verici reklamlarda tüketiciler ürüne yönelik bilgilendirilirken, dönüştürücü reklamlarda marka adı, tüketim tarzl, yaşam tarzl, kişisel ve toplumsal başarı gibi tutumların sunumu söz konusudur (Aktaran Dağtaş, 2003: 79). 1970'li yıllar kitle iletişim araçlarının yaygınlaşarak, televizyonların evlere girdiği yıllar olması açısından öncekilerden farklıdır. Televizyonun yaygınlaşması komşularla yeni sosyal ortamlar oluşturmuştur. Daha önceleri tiyatro ve sinema ile ilgilenen toplum kara kutuya teslim olmuş, Amerika kaynaklı diziler aracılığıyla bu kültürün yașam tarzının etkisi altında kalmıştır. Bu durum, Ahmet Oktay'ın deyimiyle "tüketim ideolojisinin" yayılmasında ve "meta fetişizminin" oluşmasında etkili olmuştur (Oktay, 2008: 14). Kitle iletişim araçlarının yaygınlaşması toplumlararası etkileşimi kolaylaştırmış, bir yandan kültürel benzerliklerin ortaya çıkmasını sağlarken diğer yandan da toplumsal yapının daha karmaşık hale gelmesine neden olmuştur. Ayrıca yaşam tarzlarını, çağdaș toplumdaki kadın ve erkeğin rollerinin neler olduğunu, giyim, dekorasyon ve teknoloji gibi alanlardaki trendleri izleyiciye sunarak, bunların nasıl tüketileceğini öğretme işlevi de vardır (Kaya ve Oğuz, 2010).

Tüketim yapılarındaki köklü değişimin nedenlerinden biri de çalışan kadın sayısının artması olarak karşımıza çıkmaktadır. Çalışma ortamının giyim kuşam kurallarının değișmesi, harcanabilir gelirin artması gibi nedenlerle giyim kuşama ayrılan para ve emek de artmıştır. Bilgi teknolojilerinin sağladığı hız ve kolaylık ile hem iş, hem evde geçirilmesi gereken çalışma saatlerinden arta kalan boş zamanın artması nedeniyle de boş zaman faaliyetlerine daha fazla zaman kalmaktadır (Aktan, 2013: 61).

\section{Türkiye'de Tüketim Pratiklerinin Değişimine Neden Olan Gelişmeler}

Tellan (2009: 77)'a göre tüketim kavramının anlamlandırılması için, bu eylemin tarihsel geçmişinin ve sürecin sosyolojik sonuçlarının bir arada tartışılması şarttır. Türkiye'de 1950'lerden 1990'lara kadar olan dönemde yaşanan toplumsal, kültürel, politik ve ekonomik değişim, tüketim ve tüketim kültürü olgularının ortaya konabilmesi için önemlidir (Korkmaz, 2009: 151).

Tanzimat'tan beri süregelen Batı medeniyetinin Avrupa ile özdeşleştirilmesi, yerini 1950 sonrasında Amerika deneyimine yönelik bir modernlik arayışına bırakmıştır (Kunak, 2016: 11). Cumhuriyetin ilk yıllarından itibaren Türkiye'de temel hedef sanayileşme olagelmiştir. Buna rağmen hızlı bir sanayileşme ve buna bağlı bir kentleşme durumu söz konusu olamamıștır. Ancak İkinci Dünya Savașı'nın sona ermesiyle, ülkenin kapitalist dünya sistemiyle bütünleşmesi ve bu sistemin koşulları çerçevesinde bir sanayileşme durumu söz konusu olabilmiştir (Korkmaz, 2009: 143).

İkinci Dünya Savaş'ından sonra, serbest piyasa ekonomisinin gelişmesi ve kapitalist ilişkilerin artmasına tanık olunurken, yakın zamanda başlayan Marshall Yardım Programı ile kendi içine kapanmış durumda olan Türkiye ekonomisi, dünya ekonomisiyle 
bütünleşme yolunda ilk adımı atmıştır (Yanıklar, 2006: 68). Türkiye'de 1950-1980 yılları arasındaki bu bütünleşme sürecinde "ithal ikameci" bir ekonomik model benimsenmiștir. Bu model ile birlikte 1950 'lerden sonra kentlerdeki istihdam olanakları artmıştır. Aynı dönemde tarımda makineleşme uygulamalarına da geçilince köyden kente doğru bir göç durumu söz konusu olmuştur. Göç eden bu bireyler hem gelişmekte olan sanayi sektörüne ucuz işgücü olarak, hem de üretilenlerin tüketicisi olarak işlev görmüşlerdir (Korkmaz, 2009: 143).

Türkiye'de 1970'lerin yoksulluk döneminin ardından, ekonomik dışa açılma ile beraber iç piyasada bir ürün bolluğu dönemi başlamış, bu durum toplumda yeni bir tüketim algısının oluşmasına neden olmuştur (Doğan,2014: 1). 1980 ve 1990lı yıllarda yaşanan ekonomik ve sosyolojik temelli değișmeler artık Türkiye'nin de bir tüketim toplumu olarak kabul edilmesini doğrulayan niteliklere sahiptir.

İthal ikameci modelin kullanışsız hale gelmesinden dolayı 1980'lerde yeni bir sermaye birikim modeli olan neo-liberal politikalar gündeme gelmiştir (Korkmaz, 2009: 144). 24 Ocak kararları, bugün küreselleșme denilen dünya ekonomisiyle bütünleșmeye yönelik bir adımdır. Serbest döviz kuru ve faiz hadleri uygulamaları, ekonomiyle ilgili eylemleri rant ekonomisine dönüştürürken, serbest ticaret uygulamaları ile de ithalat ve ihracat artmıştır (Dağtaş, 2003:78).

Tüm bunların sonucunda çok çeșitli tüketim malları ülkeye kolayca girebilir olmuştur. Ekonomideki değişimlerin çoğu toplumsal değerleri de kökten etkilemiștir. 1980'li yılların ortalarından itibaren tüketebilme yeteneği kitleler için oldukça önemli bir değer ve statü halini almıştır (Aktaran Dağtaş, 2003: 78). Bu yüzden bu tarihlerin Türkiye'de sosyo-ekonomik ve sosyo-kültürel alanlarda bir dönüm noktasını temsil ettiği söylenebilir. 1980'de gerçekleștirilen askeri darbe ve ardından gelen Turgut Özal iktidarı dönemi, Türkiye'de daha önceki yıllarla karşılaştırılamayacak ölçüde önemli politik, ekonomik ve kültürel alanlarda değişimler yaşanmasına yol açmıştır (Doğan, 2014: 1).

Bu süreç, 1980 sonrası ekonomik dönüşümlerin etkilediği Türkiye'nin, yeni bir kültürel kimlik oluşturmaya başladığı ve tüketim eylemini yeniden şekillendirdiği bir süreç olarak tarihe geçmiştir. (Kahraman, 2002: 96). 24 Ocak kararlarıyla atılan yeni ekonomik temellerin, kültürel ve toplumsal sonuçları, 1980'lerin ikinci yarısında, kitleler askeri darbenin baskısından kurtulduğu zaman ve yabancı sermayenin yurt içine daha fazla girdiği, ithalat-ihracat hareketliliğinin arttığı dönemlerde ortaya çıkmıştır (Doğan, 2014: 24).

90’ların başında Körfez Savaşı'na ve SSCB'nin yıkılışıyla sona eren soğuk savaşa tanık olan Türkiye, bu olaylar karşısındaki tutumları ve AB'ye yeniden başvurusu ile Batılılașma isteğini koruduğunu göstermiștir. Bu yüzden de dünya genelindeki egemen politikalara uyum göstermek zorunda kalmıştır. Bu bağlamda, Türkiye değișime zorlayıcı dıș etkenler altında post-modern ögelerle karşı karşıya kalmıştır (Halaçoğlu, 2009: 278).

Ekonomik gelişmelere ek olarak ulaşımın da kolay hale gelmesiyle, daha önce neredeyse durağan bir görünüm sergileyen șehirleşme süreci ivme kazanmış ve bu tarihlerden sonra da hızlanarak devam etmiștir. 1950'de yüzde 18 olan şehir nüfusu, 1960 'a gelindiğinde yüzde 25 'e yükselmiștir. 1970 'te yüzde 38 'e, 1980 'de ise yüzde 44 'e yükselmiştir (Yanıklar, 2006: 69). Böylelikle de tüketim kalıplarının değișmesinde etkili bir başka neden olan, çevre-merkez etkileşimi yoğunlaşmıștır. Köyden kente doğru göç eden kitleler ilk olarak kente kendileriyle birlikte alıșkanlıklarını, değerlerini, gelenekgöreneklerini ve ayinlerini de getirmișlerdir. Böylelikle köyden kente doğru bir kültürel akış gerçekleşmiştir Bu da şehirli sosyo-kültürel unsurların çözülmesi ve taşralaşma sürecinin başlamasına neden olmuştur. Bir yandan da kente göç eden bu kitlelerin zaman içerisinde köylerine, kasabalarına kısa süreli gidiş gelişleri söz konusu olmuştur. Bu gidiş gelişler, kente özgü bazı sosyo-kültürel değerlerin köy yaşantısına taşınmasına neden olmuştur. Zaman içinde kentler taşralaşma eğrisine girmiş, taşra da kentli pratiklerle 
karşı karşıya kalmıştır (Özdemir, 2012: 13). Bireyler bu etkileşim sonucunda, kendilerine yabancı olan yeni mekânlarda var olan tüketim pratiklerini zamanla benimseyerek farklılıklarını azaltma yolunu seçmişlerdir.

Bu gelişmeler ıșığında 1980 'lerden itibaren ortaya çıkan yeni kimlik politikaları farklı toplumsal kesimlerin kamusal alanda kendini ifade etmeye başlamasıyla şekillenmiştir. Bu dönemde kültürel farklılaşma ve çoğulculuk keşfedilmeye başlanmıştır. Bu anlamda "kimlik" çoğunlukla farklı kültürel, etnik ve dinsel köken veya tercihe sahip yurttaşların kendilerini ifade ediş ve toplumsal algılanış biçimi üzerinden tartışılan bir kavram haline gelmiştir (Halaçoğlu, 2009: 278).

Farklı gruplar arasındaki etkileșimin artması, alt sınıflar tarafından da tüketimin benimsenmesine yol açmıştır. Fakat bu benimseme tüketim odaklı olduğu için, özgünlüklerin ortaya çıkışı ve yine bireyin toplum içinde ne kadar tükettiği ve diğerlerinin tüketiminden ne kadar farklı olduğu çerçevesinde şekillenmektedir (Gürocak, 2010: 62). "Değişim yoluyla farklılaşmak" olgusu, moda ve tüketim ile birlikte zirveye ulaşmıştır. Toplumda aidiyet kazanmak için eldeki gelirin varlığı yeterli değildir, tüketim yapılarak gelirin görünür kılınması da gerekir (Yavuz,2013: 226). Kır hayatındaki toplum yapısının aksine birey kent yaşantısında yalnızdır. Şehrin anonim yapısı içinde kaybolup gitmemek için birey, farklılık duygusunun yaratılmasına ihtiyaç duyar. Şehirlerdeki bireylerin, iş hayatı dışında sosyal yaşantıyı paylaștıkları zamanlar nadirdir ve bu zamanlar oldukça kısadır. Bu yüzden birey, mümkün olduğunca kısa sürede çarpıcı bir izlenim uyandırabilmek zorunluluğu hisseder (Back, 1985). Bunun yollarından birisi de genelde dış görünüş özelde ise giyim olarak karşımıza çıkar.

Kente göçün sonuçları bununla sınırlı değildir. Göçle birlikte kente gelen bireyler fabrikalarda işçi olarak çalışmaya başlamış ve kazandıkları ücretlerle de ihtiyaçlarını karşılayarak yeni tüketiciler haline gelmişlerdir. Kaynaklar tasarruf amacıyla değil de mal alımı amacıyla kullanıldığında tüketim gerçekleștirilmiş olur. Kanaatkâr olan Türk toplumunun tüketim toplumuna dönüşmesinin temelleri 1950'li yıllarda atılmaya başlanmıș, 1980'li yıllarda gelişme göstermiș ve zamanla günümüzdeki şeklini almıștır. Kırdan kente göçle birlikte, tüketimin artmasının yanı sıra pek çok sosyo-kültürel farklılaşma başlamış, geleneksel değerlerde çözülmeler meydana gelmiş, batılı değerler benimsenmeye başlamıştır (Yavuz, 2013: 232).

1950ler'den itibaren kentlere göçle birlikte önceleri birbirlerinden yalıtılmış halde olan çevre ve merkez kültürleri arasındaki fiziksel ve psikolojik mesafe azalmaya başlamıştır. Ortak mekânları kullanmaya başlayan bu farklı kültürel gruplar, gündelik hayatın türlü alanlarında bir araya gelmeye başlamış, bireyi temele alan ideolojilerin benimsenmesiyle de yeni yașam tarzlarının oraya çıkmasına zemin hazırlamışlardır (Binark ve Kılıçbay, 2000: 12).

Tüketimdeki değişimde, tüketim faaliyetlerini daha etkin hale getiren bir araç olarak kredi kartının ve çok geniş bir yelpazede mal ve hizmetleri aynı çatı altında sunan tüketim mekânlarının de etkileri göz önünde bulundurulmalıdır. 1980’lerde Türk insanı kredi kartı, otomatik banka vezneleri, nakit avans, harcamaları taksitlendirme gibi tüketimi kolaylaştırıcı yeniliklerle tanışmıştır. 1980'lere kadar seçkin sınıfın ayrıcalık nesnesi olarak görülebilecek olan kredi kartı bu tarihten sonra sıradan bir nesne haline dönüşmüștür (Yanıklar, 2006: 76). Türkiye'de alışveriş merkezlerinin yaygınlaşmaya başlaması da yine 80'li ve 90'lı yıllara rastlamaktadır. Bu tarz büyük ölçekli tüketim ortamları Türk tüketicisinin gelenekselleșmiş alışveriș mantığını değiștirmede önemli roller üstlenmiştir (Yanıklar, 2006: 79-80).

Türkiye gibi endüstrileşmesini gerçekleştirmemiş ülkelerde, kitleler reklamlar aracılığıyla mümkün olduğunca tüketici olmaya ikna edilmektedir ve bu yolla çeşitli tüketim alışkanlıkları kazandırmak amaçlanmaktadır (Dağtaş ve Dağtaş, 2006: 5). Bu noktada 1980 sonrası Türkiye'de görsel medyanın ağırlık kazanması, toplumun kamusal 
bilinç ve tüketim bilinci üzerinde önemli bir etkiye sahip bir diğer etkendir (Kahraman, 2002: 85-87). Özellikle reklam sektörüne eklemlenmiş olan televizyon, sürekli olarak tüketim ideolojisini desteklemiştir. Dar gelirli kesimin orta veya üst gelir grubuna mensup kitlenin ekonomik kalıplarını benimsemesi için bir aracı rol üstlenmiştir. Oktay (1994: 268) televizyonlarda, sinemalarda, gazetelerde yayınlanan reklamlara bakarak kitle iletişim araçlarının büyük ölçüde eğlence sanayisine hizmet ettiğini, halen, en yaygın araç olan televizyonda yayınlanan programların, dizilerin, filmlerin doğrudan doğruya tüketim ile ilişkili içeriğe sahip yapımları halka sunmakta olduğunu belirtmiştir.

Henüz modernleşmesini tamamlamadan dış etkenler altında post-modern ögelerle karşı karşıya kalan 1990’lar Türkiye'sinde kimlik politikaları ve kimlik kavramı önem kazanmaya başlamıştır. Tüketim kültürü, yaşam tarzları ve bunlarının bileşimi olarak kimliklerin sunumunda en önemli görevi kitle iletişim araçları üstlenmiștir (Halaçoğlu, 2009: 268).

1970 ve 1980ler'de metropollerde islami bir burjuvazinin oluşmasıyla birlikte, yeni bir müslüman kimliği ve buna paralel bir "islami tüketicilik" de meydana çıkmıștır. Yeni gelișen tüketim alışkanlıkları, islam ile modernizmin arasında olduğu varsayılan çelişkiye tüketim alanında verilen bir cevap niteliğindedir (Akşit, Küçükkural, Şentürk ve Cengiz 2012: 58). Örtünme pratiği de sadece din temelli bir inanç uygulaması olarak değil, bireyin kendi bedenini tanımlama biçimini, bedeniyle inancı arasında kurduğu ilișkiyi simgesel olarak gösterme yollarından birisidir. Örtünme pratiğinin moda ile olan ilişkisi de islami kurallara uygun olan yaşam tarzlarının tüketim toplumuna dâhil olmasıyla ortaya çıkmıştır (Binark ve Kılıçbay, 2000: 8).

Yeni markaların gelmesi ile oluşan tüketim, tüketicinin yavaş yavaş doyuma ulaşması ile beraber yerini seçiciliğe bırakmıştır. Tüketiciler, tanıdıkları markaların arasından seçim yapabilme zevkine ve bilincine sahip olmuştur (Aktaran Doğan, 2014).

70’li yıllardan günümüze üretim sürecindeki yeniden yapılanma bireyselleşmeyi yüceltmiş ve her bireyi, tet tek hazlarını doyurması gereken tüketiciler olarak tanımlamıştır (Şahin, 2009: 137). Kapitalizmin gelişim aşamalarında tüketim kavramına farklı değerler atfedilmiş ve içinde bulunduğumuz dönemde yeni bir bağlama oturtulmuş olması, gerçekliğin yaşam tarzları ve farklılaşma talepleri ile ilişkisine işaret etmektedir (Tellan, 2009: 77). Günümüzde bireylerin tüketim aracılığıyla denetlendiği, bu olgunun bütün kimliklerin ötesine geçtiği, neredeyse dünyanın tamamında egemen hale geldiği düşüncesi baskındır. Sosyal alanda çalışan pek çok teorisyen modern toplumu tüketen bireyler ve tüketime dair olgular üzerinden anlamaya çalışmaktadırlar. Modern toplumun tüm amacının tüketimi maksimuma çıkarmak ve tüketimi estetik bir boyuta taşımak suretiyle "iyi yaşama” erişmek olduğu sonucuna ulaşılmaktadır (Tükel, 2014: 8).

İnternetin ortaya çlkması ve toplum hayatına nüfuz etmesiyle birlikte, geleneksel medya yerini sosyal medyaya bırakmaya başlamıştır. Etkileşim ve paylaşımı temele alan sosyal medya, kişilerin sadece birbirleriyle olan iletişimini etkilemekle kalmamış, markalarla olan iletişimleri için de yeni bir ortam yaratmıştır. Sosyal medya platformları geliștikçe, pazarlama alanında çok daha etkili bir șekilde kullanılmaya başlanmıștır (Sabuncu, 2009: 124). Bu platformları ve sosyal medya fenomen pazarlamasını tercih edenler arasında kozmetik ve moda sektörleri ilk sırada yer almaktadır (Mert, 2018: 1319).

Elektronik medya tüketici ve izleyici kesim üzerinde karşı konulamaz bir güce sahiptir. Post-modern imgelerle çevrilmiş bu ortamlar modanın paylaşım ve yayılım hızını en çok etkileyen unsurlardan birisidir. Modanın doğasında, sürekli olarak yeni olana atıfta bulunmak vardır, her şeyden haberdar olmayı gerektirir, hangi zaman nelerin geçerli olduğunu bilip bir yeniden çevrilme oluşturur. Moda, popüler kültürü ve kitle kültürünü bir arada tutan yapıștırıcı niteliğindedir (Baudrillard, 2013). 
Moda, kültüre ve topluma hâkim olan her akım gibi, yenilikçi bir şekilde toplumun tüketim pratiklerini etkilemektedir. Modayı takip etmek, kullanılan ürünlerin işlevini yitirmese de, yeni çeşitlerinin yeniden tüketilmesini gerekli kılar (Çınar ve Çubukçu, 2009: 283). Tüketici yaşam tarzlarındaki değişim ve neticesindeki yenilik talepleri, mevcut tedarik zincirinin değişmesi yönünde baskı uygulamıştır. 21. yüzyıla gelindiğinde, Zara ve H\&M gibi perakendeciler rekabetçi avantaj odaklarını fiyat avantajından, moda trendlerine ve tüketicilerin taleplerini hızlı bir biçimde yanıtlamaya yönelik yeniden yapılandırmışlardır (Barnes ve Lea-Greenwood, 2006: 260).

Çağdaş toplumlardaki en etkili güçlerden birisi meta estetiğidir. İnanç, eğitim ve sanat gibi geleneksel güçleri dikkate alır, onları belirli bir noktaya kadar süzer, medya ile bağlantısını kurar böylelikle de her gün milyonlarca insanın ortak hayal gücünü etkileyen en etkin güç haline gelir. Post-modern dönemde her şey bir değișim değerine sahiptir ve her şey bir metaya dönüștürülebilir. Pektaş'a göre bilgi, eşya, beden, doğa, duygu, sanat vb. her şey yeniden üretilip tüketim aracı haline getirilmiştir $(2006,92: 115)$.

\section{Gündelik Yaşam Pratikleri İçinde Modanın Yeri}

Üretim, tüketim ve tasarımla ilgili süreçler, gündelik yaşam pratiklerinde de etkili olan kültürel yorumlamayla, beğeni ve algılama kavramlarıyla ve toplumsal iletişim süreciyle yakından ilișkilidir. Bugün de geçmiște olduğu gibi metaların estetik, tasarımsal ve yapısal özelliklerin kültürel kullanım ve anlamlandırma biçimleriyle bağlantılı olduğu gerçeği geçerlidir (Dal ve Gürpınar, 2010: 38). Gündelik yaşamın modayla olan ilişkisi tüketim kültürünün önemli bir unsurudur (Köse, 2010: 79). Moda kimliğin bir ürünüdür, aynı zamanda içerisinde var olduğu toplum yapısının zihninde şekillenir, zenginleșir, kamusal alanda varlığını hissettirir, sınıfsal algılamaların yaratılmasında öncü olarak işlev üstlenir. Moda özel işaretler taşıyan bir alandır. Bu yüzden de zaman zaman moda olan davranış ya da giyim biçimleri değişim gösterir (Yağlı, 2014: 11).

Giyim, kimliğin inşası konusunda tüketim kültürünün en görünür olan biçimlerindendir, statünün ve toplumsal cinsiyetin de en belirgin göstergelerindendir. Toplumsal yapılar içerisinde konumların nasıl algılandığını ve statü sınırlarının nasıl olduğunu göstermektedir. Ancak kimliğin bir unsuru olan giyim, tüm bu sembolik sınırların kurulmasında etkili olduğu gibi yıkılmasında da etkilidir (Crane, 2003). Modanın demokratikleşmesi olgusu bu sınırların ortadan kaldırılmasına örnektir.

Modern dünyada giyim yoluyla bir teslimiyet söz konusudur, otorite ise kitlenin kendisidir. İsyan edenler ve teslim olanlar moda aracılığıyla denetlenir. Moda ürünlere yüklenen anlamlar, öncelikle toplum hayatında ön planda olan bireyler ya da kitlelerle dolaşıma çıkarılır. Baskın bir karakteri olan modanın yaptııımı, toplumsal başarı sağlama ve kabul görme ya da dışlanmadır (Yağlı, 2014: 16-17).

Modanın seslendiği toplumsal gruplar belirlidir. Moda bu gruplardan bazılarını onaylarken bazılarını dışlar. Bu yapmak için ihtiyacı olan kamusal alan günümüzde elektronik medyadır. Kamusal alanın denetimi medyaya doğru kaymıștır ve sunulmak istenen tüm görseller artık burada sergilenmektedir (Crane, 2003: 318).

Gündelik hayatın içerisinde kendine giderek daha fazla yer bulan teknoloji, onu yeniden biçimlendirmekte ve bireylere yeni mecralar sunmaktadır. Bu mecralarda bireyler en fazla kişiye en kısa yoldan ulaşabilmektedirler. Yeniden şekillenen televizyon, cep telefonları, çeșitli dijital ortamlar gibi bu yeni mecralar, reklamların yayılım hızını, gücünü ve paylaşımını artırmıştır. Bu yollarla giyilmesi kolayca benimsenemeyecek pek çok tarz hızla benimsenmekte, doğal, kabul edilebilir hale gelmekte, meşrulaştırılmaktadır (Yağll, 2014: 18). 


\section{Hızlı Moda}

Günümüzde modaya yönelik ilgi yoğun biçimde artmaktadır. Moda, değişim, yaratıcılık ve pazarlama olmak üzere üç temel üzerine kurulmuştur. Değişiklik modanın esas ögesidir. Bazı markaların sezon odaklı geleneksel değişiklik anlayışından sıyrılarak yeni mağazalar ve küçük koleksiyonlar ile sürekli olarak müşterilerine yeni ürünler sunmaları "Hızlı Moda" kavramını doğurmuştur (Dal ve Gürpınar, 2010: 28).

2000'li yılların başında İtalyan moda markalarının ve özellikle Gucci'nin karlılığında \% 50 oranında bir azalma olmuştur. Ancak takip eden birkaç yıl içinde moda ekonomik sıkıntılara karşı koyarak yeniden kar getirmeye başlamıştır. 1998'den 2002'ye kadar olan süreçte durgun olan ekonomik büyümeye rağmen H\&M, Zara, Mango gibi cadde mağazalarında satışların ikiye katlandığı gözlenmiş, bu durum "modanın cazibesi" olarak nitelendirilmiştir (Tungate, 2008: 28).

Hızlı modanın pazarlama mantığı, tüketicileri belirli bir sıklıkta satın almaya, satın almaya dair kararlarını da hızlı vermeye teşvik etmek çerçevesinde şekillenmiştir. Bu mantık, geniş ürün yelpazesine sahip olmak, modelleri küçük miktarlarda üretmek gibi uygulamalarla başarıya ulaşmıştır (Tüfekçi, 2014: 51). Hızlı moda, tüketici tatminini üst seviyede karşılamak için, mağazalara yeni moda ürünleri getirme zamanı ve satın alım döngüsünün dâhil olduğu süreci azaltmayı hedeflemektedir (Byun ve Sternquist, 2008: 139).

Ürünün tüketiciye sunulma süresinin kısaltılması, hızlı modayı destekleyen en önemli prensiptir. Bu nedenle hızlı moda perakendecileri iş stratejilerini, depodaki ürünlerin mümkün olduğunca çabuk tüketiciye sunulması üzerine kurmaktadırlar. Dolayısıyla sürekli değișen ve gelișen tüketici talebi, kısaltılan sunum ve tüketim süresi, hızlı moda kavramının destekleyici gücü olarak karşımıza çıkmaktadır (Barnes ve LeaGreenwood, 2010: 761).

Cachon ve Swinney (2011: 778)'e göre hızlı moda sistemi en az iki unsurdan oluşmaktadır. Bu unsurlardan ilki belirsiz taleplerle ihtiyacı en uygun bir șekilde eșleștirebilmeyi sağlayan kısa üretim ve dağıtım zamanı, ikincisi ise oldukça șık ürün tasarımıdır.

Hızlı modayı etkileyen faktörler kıtlık algısı, tükenebilir algısı ve düşük fiyat algısıdır. Bunlara ilaveten hızlı modayı benimseterek yeni ürünlerin satışını teşvik etmek için pazarlamacılar tarafından kullanılan bir başka uygulama da planlı eskitmedir. Planlı eskitme, yenilerinin benimsenmesini sağlamak için işlevini sürdüren ürün ve stillerin tüketici zihnindeki çekiciliğinin azaltılmaya çalışılmasıdır. Tüketiciler bu uygulamalar karşısında değişim sürecine tepkisiz kalamayarak işletmelerin istediğini yapmakta ve psikolojik eskitme uygulamalarına yanıt vermektedir (Tüfekçi, 2014: 27).

Ürün çeşitliliği ve hızlı yenilenme süresiyle tüketicilerin davranış kalıplarında önemli değişiklikler meydana gelmektedir. Geniş çeşitlilikteki ürünler ve hızlı model döngüsü ile tüketicilerde yapay bir kıtlık algısı oluşturulmaktadır. Yapay kıtlık algısı ile ürünlerin hızlı tükenmesi olasılığına karşı, tüketicilerin beğeni duydukları ürünlere daha yüksek fiyatlar ödemeleri sağlanmaktadır. Küresel markalar tarafından ortaya atılan ve aslında var olmayan kıtlık algısı ile benimsetilen hızlı moda kavramı, tüketicileri moda ürünleri almaya yönelik güdülemektedir (Aksu vd., 2011, 56). Araştırma sonuçları göstermektedir ki, Zara'nın müșterileri yılda on yedi kez mağazaya uğrarken, Londra mağazalarının daimi müșterileri buraları yılda dört kez ziyaret etmektedir. Ürünler belirli sayılarda sunulduğundan tüketici bunu almazsam bir daha bulamayacağım düşüncesine kapılmaktadır (Dal ve Gürpınar, 2010: 41).

Tarihsel açıdan bakıldığında modanın ilk modelini, lüks kavramı oluşturmaktaydı ve bu durum sınıf ayrımını belirginleştiren bir niteliğe sahipti, ikinci model olan hazır giyim yaşam biçimlerine odaklanıyordu. Hızlı moda olarak adlandırılan son model ise 
tatmin gibi yeni "geçici" kimliklere ait çağrışımlar yapmaktadır (Simona Segre, 2005: 47). Hızlı moda, müşterilerine altı hafta önce podyumda gördükleri son modayı alabilecekleri fiyatlarla sunmaktadır (Dal ve Gürpınar, 2010, 37). Hızlı moda ile birlikte, moda elit sınıfa ait olmaktan çıkarak, demokratikleşmiştir. Buna rağmen hem bazı tasarımcılar tarafından tasarım kavramının önemini yitirmesine sebep olduğu konusunda, hem de sosyal bilimciler tarafından aşırı tüketimi teşvik ediyor olması anlamında eleștirilere de maruz kalan bir moda anlayıșıdır (Dal ve Gürpınar, 2010: 38-39; Kipöz ve Atalay, 2015: 109).

Moda ürünler sürekli yenilenerek ve hızlı tüketilerek, anlamını çabuk yitirmekte ve aynı hızla daha yeni olan ürünler, eskilerinin yerine geçmektedirler. Bunlara ilaveten hızlı moda ürünlerinin oldukça çeşitli ve nispeten ekonomik olması, tüketicinin beklentilerini zamanla daha da arttırmaktadır (Başkaya, 2010: 27).

Kitlesel tüketimin artması ve moda trendlerinin hızla değişmesi Fletcher'in (2008) da dediği gibi demode olarak kabul edilen pek çok moda ürünün 'atık' olarak değerlendirilmesine yol açmaktadır. Doğrusal bir yapıya sahip olan moda sisteminin işleyiși dört aşamadan geçer. Bunlar; tasarım, üretim, tüketim ve elden çıkarma aşamalarıdır (Kipöz, Atalay, 2015: 108). Bu süreç kısaldıkça dolaşımda kalan ürünlerin miktarı da artmakta ve hem üretim sürecindeki atıklar hem de ürünü elden çıkarma sürecinde sürdürülebilirlik kavramı ile tezat bir durum ortaya çıkmaktadır. Hızlı moda markaları bu durumun da farkına varmaya bașlamıș ve H\&M gibi markalar sürdürülebilirliği ve buna yönelik uygulamaların șeffaf bir șekilde ortaya konmasını bir şirket politikası haline getirmeye başlamıştır.

Hızlı moda ile birlikte büyük markalar ucuz ve şık houte coture üretim yapabildiklerini de kanıtlamıșlardır. Hızlı moda üreticileri ünlü tasarımcılarla ișbirliği yapmaktadırlar ve uzman perakendiciler de bundan dolayı oldukça memnundur. Hızlı moda tüm eleștirilere rağmen fırsatları yakalayabilen ve anlayan bir moda anlayışı olarak nitelendirilmektedir (Dal ve Gürpınar, 2010: 37).

\section{Sonuç}

Dünya genelinde yaşanan değişme ve gelişmelerin tüketim pratikleri üzerindeki etkisi pek çok ve çeşitlidir. Endüstrinin gelişmesi sonucunda maliyetler azalarak tüketim alt sınıflar için de ulaşılabilir bir hale gelmiştir. Bu durum üretim fazlasının ortaya çıkması ile sonuçlanmış ve özellikle alt sınıfların lehine bir gündem oluşturmuştur. Bu noktada öncelikle değişimin, tüketimde gerçekleşen demokratikleşmeye neden olduğu düşünülebilir. Alt sınıfların da dâhil olduğu yeni tüketici grupları post-fordist dönem uygulamalarıyla ve medya ile tanıştıktan sonra ise ihtiyaçtan öte amaçlarla tüketim yapma firsatına sahip olmuştur.

Üretimin egemen olduğu dönemden, tüketimin egemen olduğu döneme doğru bir geçiş yaşanırken bu durum tüketici gruplarının parçalanarak çoğalmasına sebep olmuştur. Türkiye özelinde ise üretimi gerçekleştirmeden tüketim pratiklerini uygulayabilmek bir takım koşullara bağlı olarak gelişme göstermiștir. Bunların başında Dünya Ekonomisi ile bütünleşme sürecinin başlangıcı olan 24 Ocak kararları olarak anılan ve askeri darbe ile de pekiştirilen ekonomik dışa açılma uygulamaları gelmektedir. Doğan'ın (2014) da ifade ettiği gibi 12 Eylül Askeri darbesi ve 24 Ocak kararları, 1980 sonrası dönemde toplum kültürü üzerinde son derece radikal sayılabilecek değișimleri yaratan belirleyici olaylar olmuştur.

Tarımda makineleşmeye geçme ile başlayan iç göçler, kentlerdeki endüstriye işgücü olarak eklemlenmek amacıyla artarak devam etmiş ve mekânsal sınırların azalması ile sonuçlanan çevre-merkez etkileşimini başlatmıştır. Yeni mekânlardaki kesişmeler sırasında bireyler, köklerinden kopmama güdüsüyle hareket etmeye ve kırsal yaşantının pratiklerini devam ettirmeye çalışmışlardır. Ancak bir yandan da kabul 
görmek ve dışlanmaktan kaçınmak gibi amaçlarla kentli yaşam tarzlarını benimsemek durumunda kalmışlardır. Bu ikilem zamanla medya ile de desteklenmeye başladıkça günümüzde varlığı inkâr edilemeyecek çok kültürlü bir yapı kaçınılmaz olarak karşımıza çıkmıştır.

Toplumun kültür ve eğlence anlayışında, eğlenme, giyim, yeme-içme, çalışma, eğitim pratiklerinde, kısacası yașayışında köklü değişimler ortaya çıkmıștır. Ekonomik uygulamalardaki bu değişimlerden de önce başlayan göç hareketleri ile de toplumun homojen yapısı değişmeye, farklı kültür ve yaşamlar iç içe geçmeye başlamıştır. Bu durum bireyi kent hayatının karmaşasında başlarda silikleştirse de, tüketim imkânı elde etmesiyle birlikte, birey tüketerek ve tükettiğini göstererek ortama uyum sağlayabilme yeteneği geliştirmiștir.

Yeni tüketim sistemi, giyim markaları ve günlük yaşama dair birçok ithal ürünün elde edilmesine olanak sağlamıştır (Doğan, 2014: 1). Toplumdaki ekonomik dengelerin değişmesi paralelinde modaya yüklenen önemin artması Türkiye'ye de hızlı modanın sıçraması ve gelişmesinde başlıca nedenler olarak karşımıza çıkmaktadır (Hacıola, 2016: 32). Bașta toplumun sosyal yapısındaki değișimler ve tüketicilerin eğitim seviyelerinin artması hazır giyim sektörünün temelini oluşturan müşteri profilinin değişimine ve gelişimine yol açmıştır. İletişim araçlarının yaygınlaşması ve gücünün artması ile birlikte daha hızlı haberdar olma ve takip etme daha kolay hale gelmiștir. Tüketicilerin yeniliğe ve değişime karşı daha duyarlı bir hale gelmesi, hazır giyim sektörünün temelini oluşturan müşteri isteklerinin daha belirgin ve yön verici olmasına neden olmuştur (Haciola, 2016: 32).

Bocock tüketimi toplum yapısında inşa edilen tarih temelli bir değișim olarak tanımlamaktadır (Bocock, 2009). Tellan'a göre ise tüketim özerk bir etkinlik değildir, farklı toplumsal grupların günlük pratiklerini icra ederken geleceğe dönük arzularını geçmiş deneyimleriyle buluşturduğu bir süreçtir (2009: 100). Bu açılardan bakıldığında, diğer pek çok endüstride olduğu gibi moda endüstrisi de tüketici beklentilerine uyum sağlamaksızın ve hassasiyetlerine özen göstermeksizin varlığını sürdüremez. Bunların neler olduğunu bilmek ise bireylerin mevcut tüketim mantığına nasıl evirildiğini bilmek, geçmişteki olaylardan nasıl etkilendiğini neden sonuç ilişkileriyle kavramakla mümkündür.

\section{KAYNAKÇA}

AKSU, M., PEKTAȘ, G. ve KARABOĞA, K. (2011). Concepts of fast fashion and artificial scarcity in marketing in the 21th century: Tchibo example. Journal of Naval Science and Engineering, 7(1), 48-70.

AKȘíT, B., KÜÇÜKKURAL, Ö., ŞENTÜRK, R. ve CENGIZ, K. (2012). Türkiye'de dindarlık, muhafazakarlık ve laiklik ekseninde inanma biçimleri ve yaşam deneyimler (2. bs.). İstanbul: İletişim.

AKTAN, C. (2013). Tüketici temelli moda değeri: Hızlı moda sektöründe bir uygulama. Doktora Tezi. İstanbul: Marmara Üniversitesi Sosyal Bilimler Enstitüsü.

BARNES , L. ve LEA-GREENWOOD, G. (2006). Fast fashioning the supply chain: Shaping the research agenda. Journal of Fashion Marketing and Management, 10(3), 259271. https://doi.org/10.1108/13612020610679259

BARNES, L. ve LEA-GREENWOOD, G. (2010). Fast fashion in the retail store environment. International Journal of Retail ve Distribution Management, 38(10), 760772. https://doi.org/10.1108/09590551011076533 
BAŞKAYA, O. (2010). Günümüzde modanın algılanıș biçimi. Yayımlanmamış Yüksek Lisans Tezi. Mimar Sinan Güzel Sanatlar Üniversitesi Sosyal Bilimler Enstitüsü. BAUDRILLARD, J. (2013). Tüketim toplumu (6. b.). İstanbul: Ayrıntı Yayınları.

BHARDWAJ, V. ve FAIRHURST, A. (2010). Fast fashion: Response to changes in the fashion industry. The International Review of Retail, Distribution and Consumer Research, 20(1), 165-173. https://doi.org/10.1080/09593960903498300

BINARK, M. ve KILIÇBAY, B. (2000). Tüketim toplumu bağlamında Türkiye'de örtünme pratiği ve moda ilişsisi. Ankara: Konrad Adenauer Vakfı.

BOCOCK, R. (2009). Tüketim. (İ. Kutluk, Çev.) Ankara: Dost.

BYUN, S.-E. ve STERNQUIST, B. (2008). The antecedents of in-store hoarding: measurement and application in the fast fashion retail environment. The International Review of Retail, Distribution and Consumer Research, 18(2), 133-147. https://doi.org/10.1080/09593960701868241

CACHON, G. P. ve SWINNEY, R. (2011). The value of fast fashion: Quick response, enhanced design, and strategic consumer behavior. Management Science, 57(4), 778795. https://doi.org/10.1287/mnsc. 1100.1303

CRANE, D. (2003). Moda ve gündemleri. İstanbul: Ayrıntı Yayınları.

ÇALIŞKAN, A., KARACASULU, M. ve ÖZTÜRKOĞLU, Y. (2016). Hızlı moda markalarında çevik ve esnek tedarik zinciri yönetimi. Celal Bayar Üniversitesi Sosyal Bilimler Dergisi, 14(4), 49-74. https://doi.org/10.18026/cbayarsos.280471

ÇETINKAYA, Y. (1992). Reklamcılık. İstanbul: Ağaç Yayınları.

ÇINAR, R. ve ÇUBUKÇU, İ. (2009). Tüketim toplumunun şekillenmesi ve tüketici davranışları karşılaştırmalı bir uygulama. Atatürk Üniversitesi Sosyal Bilimler Enstitüsü Dergisi, 13(1), 277-300.

DAĞTAȘ, B. (2003). Reklamı okumak. Ankara: Ütopya Yayınevi.

DAĞTAŞ, E. ve DAĞTAŞ, B. (2006). Tüketim kültürü, yaşam tarzları, boş zamanlar ve mdya üzerine bir literatür taraması. Eğitim Bilim Toplum Dergisi, 4(14), 4-31.

DAL, V. ve GÜRPINAR, M. (2010). Hazır giyim sanayinde hızlı moda kavramı ve bir model önerisi. İstanbul: İstanbul Sanayi Odası.

DOĞAN SÖZÜER, Z. (2014). 1980 sonrası toplumsal dönüşümleri moda tasarımı alanına etkisi. Sanatta Yeterlik Tezi. İstanbul: Haliç Üniversitesi Sosyal Bilimler Enstitüsü.

FLETCHER, K. (2008). Sustainable fashion and textiles: Design Journeys. Environmental Science and Technology, 45(21), 9175-9179.

GÜROCAK, T. (2010). Tüketim ve yaşam tarzları olgularının "Gossip girl" dizisi örneğinde sunumuna ilişkin içerik çözümlemesi. Yüksek Lisans Tezi. Eskişehir: Anadolu Üniversitesi.

HALAÇOĞLU, B. (2009). Tüketim kültürü, yaşam tarzları ve 1990'lı yıllar: Yeni kuşak Türkiye sinemasında "marjinal" kimlikler". B. Dağtaş, ve E. Dağtaş içinde, Medya, Tüketim Kültürü ve Yaşam Tarzları (s. 267-302). Ankara: Ütopya Yayınevi.

KAHRAMAN, H. B. (2002). Postmodernite ve modernite arasında Türkiye. İstanbul: Everest.

KARAKAȘ, M. (2006). Yeni yoksulluk bağlamında sosyal kimlik ve tüketimde eşitsizlik. Gazi Üniversitesi İktisadi ve İdari Bilimler Fakültesi Dergisi, 7(2), 1-16.

KAYA, K. ve OĞUZ, Z. N. (2010, Aralık). Üniversite gençliğinin alışveriş tercihlerinde tüketim kültürünün rolü. Süleyman Demirel Üniversitesi Fen Edebiyat Fakültesi Sosyal Bilimler Dergisi(22), 147-164.

KIPÖZ, Ș. ve ATALAY, D. (2015). Etik modanın temsiliyeti bağlamında vaatleri ve çelişkileri: 'etik moda' ne kadar etik sunuluyor? Dokuz Eylül Üniversitesi Güzel Sanatlar Fakültesi (Yedi), 14(14), 101-115. https://doi.org/10.17484/yedi.98156 
KORKMAZ, N. (2009). Türkiye'de tüketim kültürü ve mekansal ayrıșma. B. Dağtaş, ve E. Dağtaş içinde, Medya, Tüketim Kültürü ve Yaşam Tarzları (s. 142-164). Ankar: Ütopya Yayınevi.

KÖSE, H. (2010). Medya ve tüketim sosyolojisi. İstanbul: Ayraç Yayınları. İstanbul: Ayraç Yayınları.

KULA, N. (2012). TV dizileri yoluyla yeniden üretilen tüketim kültürü. Tarih Kültür ve Sanat Arastırmaları Dergisi, 1(4), 507-530. http://dx.doi.org/10.7596/taksad.v1i4.121

KUNAK, G. (2016). Kadın bedeninin gösterimi: popüler kültür ve Sanat (19701980). Yüksek Lisans Tezi. Ankara: Hacettepe Üniversitesi Sosyal Bilimler Enstitüsü.

MERT, Y. L. (2018). Dijital pazarlama ekseninde influencer marketing uygulamaları. Gümüşhane Üniversitesi İletişim Fakültesi Elektronik Dergisi, 6(2), 12991328. https://doi.org/10.19145/e-gifder.431622

OKTAY, A. (1994). Türkiye'de popüler kültür. İstanbul: Yapı Kredi Yayınları.

ÖZDEMİR, E. (2009). Yaşam tarzlarının sanal mekanlardaki sunumu: bir cazibe merkezi olarak "siberalem" örneği. B. Dağtaș, ve E. Dağtaș içinde, Medya, Tüketim Kültürü ve Yaşam Tarzları (s. 364-402). Ankara: Ütopya Yayınevi.

ÖZDEMİR, H. (2012). Türkiye'de iç göçler üzerine genel bir değerlendirme. Akademik Bakış(30), 1-18.

PEKTAŞ, H. (2006). Moda ve postmodernizm. Doktora Tezi. Konya: Selçuk Üniversitesi Sosyal Bilimler Enstitüsü Güzel Sanatlar Eğitimi Anabilim Dalı Resim İș Öğretmenliği Bilim Dalı.

SABUNCU, O. B. (2019). Sosyal medya pazarlamasında ünlü ve fenomen kullanımı tercihi: Hızlı moda sektörü örneği. Yüksek Lisans Tezi. İstanbul: İstanbul Kültür Üniversitesi Lisansüstü Eğitim Enstitüsü.

SEGRE, R. S. (2005). China and Italy: Fast fashion versus prêt à porter. Towards $\mathrm{A}$ New Culture of Fashion. Fashion Theory, 9(1), 43-56.

https://doi.org/10.2752/136270405778051527

ŞAHIN, Ç. E. (2009). Tüketim toplumu: "mükemmele evrilen politika". B. Dağtaş, ve E. Dağtaş içinde, Medya Tüketim Kültürü ve Yaşam Tarzları (s. 103-14). Ankara: Ütopya Yayınevi.

TELLAN, D. (2009). Tüketim kavramını anlamlandırmak: Tarihi ve sosyalojisi. B. Dağtaş, ve E. Dağtaş içinde, Medya, Tüketim Kültürü ve Yaşam Tarzları (s. 76-102). Ankara: Ütopya Yayınevi.

TUNGATE, M. (2008). Fashion brands, branding style from Armani to Zara. Kogan Page Publishers.

TÜFEKÇİ, İ. (2014). Hızlı moda ortamında moda bilincinin ürün iade davranışları üzerindeki etkisinin araștırılması. Yüksek Lisans Tezi. Erzurum Üniversitesi Sosyal Bilimler Enstitüsü.

TÜKEL, İ. (2014). Tüketimin yeni aktörleri: "Y kuşağı". Hacettepe Üniversitesi Sosyolojik Araştırmalar E-Dergi.

ÜSTÜN, B. ve TUTAL, O. (2008). Tüketim alışkanlıklarındaki değişimler ve bu değişimlerin alışveriș mekânlarına etkisinin Eskişehir örneğinde irdelenmesi. Anadolu Üniversitesi Sosyal Bilimler Dergisi, 8(2), 259-282.

YAĞLI, S. (2014). Gündelik hayatın bir alanı olarak moda aracılığıyla kültürün yeniden inșası. Akdeniz Sanat Dergisi, 4(7), 157-162.

YANIKLAR, C. (2006). Tüketimin sosyolojisi. İstanbul: Birey Yayıncllık.

YAVUZ, Ş. (2013). Türk toplumunun tüketim toplumuna dönüşümünde reklamcılığın rolü. İletişim Kuram ve Araştırma Dergisi(36), 219-240. 


\section{Summary}

Fashion consumption has been under the control of elite classes for hundreds of years. For some reasons, in both worldwide and in Turkey fashion has begun to democratize. Now, all segments of the society can consume fashion products. This change in fashion consumption is in line with the change in general consumption patterns. However, there are also some unique dynamics regarding fashion.

In order to understand the change in consumption, it is important to understand the change in production practices, technological innovations, transportation that has become easier, the media becoming part of daily life, and the globalization process of the world economy. When all these are understood with their reasons, it may be possible to comprehend the changing perspective on consumption.

The excess supply caused by the increase in production caused the consumption to increase. In this case, one of the effective factors is the increasing of technological innovations. In addition, technological development has enabled the media to become widespread and transportation opportunities to improve. The widespread use of media in daily life not only provided information about products and services, but also caused new needs to be felt by consumers. With the facilitation of transportation, both individuals and objects became easier to move.

In addition to these changes in the macro-level, the situation in Turkey must also not be ignored. Consumption practices in Turkey began to change after years of 1950s. Internal factors that provide change are reasons such as increased internal migration events, practices aimed at integration with the world economy, and the rising political Islamist movement.

With the transition to mechanization in agriculture, the masses in the villages started to migrate to the city. These masses had to adopt the consumption practices of their environments in order not to be excluded from life in new spaces. In addition, these people both participated in production as workers in factories and benefited from increased production as consumers. Efforts to integrate with the world economy started before the 1980 coup. And it was tried to be reinforced after the coup. As a result, a great variety of consumer goods began to enter the country.

Fast fashion has appeared also in Turkey. Because the meaning of fashion has changed parallel with the change in consumption. With the widespread use of communication tools and ability to be informed faster, consumers have become more sensitive to innovations and became more visible.

The fashion industry cannot survive without complying with these sensitivities and expectations of consumers. Knowing what these are is possible by understanding how individuals evolve into current consumption logic and by understanding how they are affected by past events through cause and effect relationships. 